\title{
Culture Shock Experienced by Foreign Workers
}

\author{
Diah Ayu Rafika, S.Pd \\ English Education Study Program, Muhammadiyah University \\ Palembang, Indonesia; \\ Prof. Dr. Indawan Syahri M.Pd \\ English Education Study Program, Muhammadiyah University \\ Palembang, Indonesia; \\ Rini Susanti, S.Pd., M.A \\ English Education Study Program, Muhammadiyah University \\ Palembang, Indonesia;
}

\begin{abstract}
The purpose of this study is to investigate various aspects of culture shock experienced by foreign workers and how they deal with culture shock. The study further documented various aspects of culture shock such as language, environment, friends at work, food, dress etc., and also how to deal with it. The data were collected from 4 subjects through a semi-structured interviews via WhatsApp with Indonesian who worked in various countries (Lebanon, Australia, Malaysia, and Japan). One of the major findings of this study is that Indonesian foreign workers who worked overseas experienced cultural shock both in similar and different aspects of culture shock. Six aspects among the ten were experienced by all of the four subjects. Meanwhile, the rest four aspects were only experienced by some of them. This study documented ten different categories of culture shock aspects that can be experienced by people while they are working in foreign countries.
\end{abstract}

Keywords: culture, culture shock, workers, foreign workers

\section{INTRODUCTION}

Culture refers to many different aspects. Every place has its own culture that makes them different with other places- different language, norm, educational system, weather, food, dress, and so on. People will find it different by visiting those place or even staying there in order to work, study, or take a holiday in the new place. When they start to experience the new culture they will start to experience culture shock at the same time.

There are many articles and studies discussed about foreign students who experienced culture shock, but only a few discussed about foreign workers. In fact, foreign workers are also experienced culture shock when they work in a new country. Foreign workers might be someone who sent by their company to work abroad. Some of foreign workers usually received a training before they begin to work in a new country and some are not. There are many kinds of training, it can be a language training, cultural training, and so on.

In Indonesia there is term known as Tenaga Kerja Indonesia (TKI). Irawan (2014) states that TKI means individuals who are able to work in order to produce services to meet the needs of their life (p.28). The purpose of their leaving are mostly to change their life because for them it is hard to find work in Indonesia. According to Sziraczki \& Reerink (2004), there are six billion unemployment within age of fifteen until twenty nine years old in Indonesia, these are the three-quarters from the total of the unemployment (p.7). It shows the reason of why people 
choose to be TKI. Sometimes certain situation force someone to face something without planning it. Someone who send by their company to work in other country or someone who go to other country because they have to change their life. Leaving their country and work in a new place will lead them to face and experience culture shock.

According to Syahri \& Susanti (2016), people come from the same cultural background with the same language too, therefore it is difficult for them to communicate and develop their ideas when they talk about the target culture which is new for them (p.2). In other words, it means that the foreign workers may experience the shock in form of language shock in the foreign country where they are working. In addition, Susanti (2016) states that good language (writing) will be understandable both by both parties (the writer and the readers) (p.1063). It can be inferred that the foreign workers' ability to communicate in the foreign country will determine how far they will experience the culture shock itself. It will be easier for them to face the culture shock especially language shock if they are able to communicate fluently by using the foreign language.

Regarding to the background, the writer need to find the aspects of culture shock experience by foreign workers and then find the way they deal with culture shock as the resolution, which is why the writer was interested in conducting a research entitled "Culture Shock Experienced by Foreign Workers".

\section{CULTURE}

Every activities doing by people are considered as their culture. According to Brooker (2003), culture as an indispensable but multi accented term with a complex and still open history, which in itself expresses the complexity of general human history (p.58). In short, culture could tell us anything about human's life, it is all about how human travel through their life. It is include all of the aspects that related with human and their environment.

G. Hofstede, J. Hofstede, \& Minkov (2010) state that culture is learned, not innate, it derives from one's social environment rather than from one's genes (p.6). It means that, the existence of culture is more related to social environment than genes. According to Avruch (2002), culture is a derivative of individual experience, something learned or created by individuals themselves or passed on to them socially by contemporaries or ancestors (p.5). In short, culture is something made by human to create their social life and it known as their tradition that makes them different with other individuals.

\section{CULTURE SHOCK}

According to Pelling (2000), culture shock is originally an emotional reaction that is a result of not being able to understand, control or predict one's behavior (p.6). In other words, when someone is not able to understand about something new- one's behavior, the person emotionally will get confuse or even stress. It is not easy for someone to directly fit with a new place or new people. They do not know what to say or what to do, how to act around the new people or even to speak there.

\section{THE STAGES OF CULTURE SHOCK}

According to Winkelman (1994), there are four primacy phases of culture shock, as follows:

1) The honeymoon or tourist phase. The first phase is the typical experience of people who enter other cultures for honeymoons, vacations, or brief business trips. It is characterized by interest, excitement, euphoria, sleeplessness, positive expectations, and idealizations about the new culture. 
2) The crises or culture shock phase. When the honeymoon phase give way to crises depends on individual characteristics, preparations and many other factors. The crises phase may emerge immediately upon arrival or be delayed but generally emerged within a few weeks to a month

3) The adjustment, reorientation, and gradual recovery phase. The third phase in concerned with learning to adjust effectively to the new cultural environment.

4) The adaptation, resolution, or acculturation phase. The fourth stage is achieved as one develop stables adaptation in being successful at resolving problems and managing the new culture. (p.122)

When people visit new country, they will feel very excited at the first time and everything seems very interesting. When it comes at the second stage, the occurrence of the second stage of culture shock will be different from one person to another, depends on their preparation to deal with it. The third and the fourth stages of culture shock are generally the same.

\section{KINDS OF FOREIGN WORKER}

The term migrant is well known all over the world as persons moving from one country to another country for certain purpose, especially in seeking jobs. According to Zikic, Perez, \& Cerdin (2010), migrants' career are both risky and unpredictable, they also settle in another country for a long period of time (p. 668). It means, there are probability that migrants will stay permanently in the host country they are work in. Ariss \& Crowley-Henry (2013) state that "management studies use the term migrant when discussing the work experiences of unskilled individuals, having less educated backgrounds, and originating from less-developed countries (p. 82). In short, migrants are mostly persons who are less professional because of their limited skills.

Beside migrant, there is a term known as assigned expatriate (AE). According to Przytuła (2015), assigned expatriates are persons who work in other countries because they have been sponsored and assigned by their parent organizations to the foreign location (p. 94). In other words, the decision of their leaving is not in their hands, the company or organization is the one who decide it. It does not matter whether they want to go or not, they do not have any choices but leave then work in foreign country.

In addition to migrant and assigned expatriate (AE), the term self-initiated expatriate (SIE) is also exist. A study found that "such individuals who themselves make decision to live and work abroad have been called self-initiated expatriates (Przytuła, 2015, p. 96). It can be inferred that a self-initiated expatriate have an opportunities to decide whether to work abroad or not, the decision is in their hands, it is in contrast with assigned expatriate who cannot make decision by themselves.

\section{INDONESIAN FOREIGN WORKER}

The term Tenaga Kerja Indonesia (TKI) is much known in Indonesia. TKI means persons who are Indonesian citizen working in another country. According to Irawan (2014), there are two types of TKI, as follows:

\section{TKI through Departemen Tenaga Kerja (DEPNAKER)}

DEPNAKER is the corporation who manage everything related to TKI. Every person who wants to be a TKI as legal TKI must follow every procedures which settled by the government, start from fulfill the pre-requirement, get the permission or legalization from the government who manage things about TKI, such as DEPNAKER, and so on. 


\section{Illegal TKI}

People have assumption that following the government procedures is complicated, too many administrative requirements needed, that is why they are not interested in government program. They prefer to follow people who usually send TKI abroad illegally (tekong) even if they have to pay double cost. They want the process to be fast because they do not want to wait too long. They just need to give some money and everything is done, but through DEPNAKER they have to do many administrative requirements. (pp. 30-32)

Based on the explanation stated, it can be concluded that there are two types of TKI, they are legal TKI and illegal TKI. It depends on which way they take to be a TKI. When they follow the procedure from the government they considered as legal TKI, but if they do not, they are considered as illegal TKI.

\section{ASPECTS OF CULTURE SHOCK}

Culture and its aspects are really related to culture shock. Those aspects which different in every place in this world create groups of people with their own culture. Someone who experience others' culture will experience culture shock, it is because the differences in aspects of culture.

Language is one of the aspects of culture. The differences between language in different place can cause culture shock or known as language shock. According to Fan (2010), language shock is one of the less recognized aspects of cultural shock as its emotional impact is not so overtly strong that it could cause great harm or destruction to individuals who experience it (p. 42). Which means, people rarely realize that language can cause culture shock.

In addition, a study found that there are fourteen aspects related to culture shock, they are as follows: communication, dress, ethics, individualism/collectivism, food, language, structure, perception, power distance, religion, rules, time orientation, traditions and weather (Rajasekar \& Renand, 2013, p. 149). These aspects of culture are different from place to place, the way people communicate are different one another, some people may communicate by joining hands instead of shaking hands, men kissing each other and touching each other nose to nose, and so on. The way people dress is also different, some people use veil, some are not surprised when they see people naked in public and so on. The same situation is also happen on other aspects. It shows that every aspects of culture will lead to culture shock because they are different.

\section{METHODOLOGY}

The study is in the field of qualitative study. The type of this study is descriptive qualitative research. According to Richards and Schmidt (2002), qualitative research that aims at causal explanation of phenomena through the identification of variables which can be made the basis of experimental investigation (p.436). It means that, qualitative related to an explanation about cause and effect of something and it can be the beginning of an experimental research. The researcher demanded to be able to see everything about certain phenomena from someone's point of view and understand it. That is why we can say that there should be an in-depthobservation and in-depth-interview in a qualitative research.

In this study, there were two main sources of the data that the writer used (i.e. primary data and secondary data). The primary data in this study refers to the information that got from the subjects through interviews, while the secondary data related to other references to support this study. 
The subjects of this study are those who are from Indonesia working overseas. The writer took four subjects in this study. The first subject is a member of Tentara Nasional Indonesia Angkatan Darat (TNI- AD), he sent to Lebanon as a peacekeeper in the conflict area there. The second subject is also member of TNI- AD, he sent to Australia to work there. The third subject is someone who work in Malaysia, he works as a construction laborer there. The fourth subject in this study is someone who works in Japan as a welder in producing heavy equipment. In selecting the subjects in this study, the writer got the second subject from the first subject, the third from the second, and the fourth from the third. All the subjects gave all the information needed to answer the problems in this study related to culture shock they experienced while working overseas.

In this study, the writer used interview in collecting the data. Syahri, Sulaiman, \& Susanti (2017) state that interview is technique or method of collecting data through direct communication between the interviewer and the respondent (p. 83). In this case, direct communication needed because the interviewer ask questions directly to the respondent and get the answer directly from the respondent.

The questions of the interview consists of twelve main questions and some follow up questions. This interview is considered as semi-structured interview. All of the subjects had given an interview via whatsapp in form of chat. Some of them are overseas and some of them are in different town. That is why it was almost not possible to have a face-to-face interview with the subjects. Even if it was possible, it will take longer time and also money. The interview was in Bahasa Indonesia in order to avoid misunderstanding and to collect as much as information that the writer can get.

In analyzing the data of this study, the writer used coding technique. This technique made the process of analyzing the data easier and efficient. In addition, Bogdan \& Biklen (2003) state that coding is the process of developing categories to sort data, also used to refer to the sorting process (p. 258). In other words, when the writer used coding technique she wrote codes to make her easier in analyzing the data.

\section{FINDINGS}

\section{Aspects of Culture Shock and How to Deal with it}

When people experiencing culture shock during their time in the host country or in this case, when they are working in a host country, this psychological reaction is inseparable from every parts of culture or its aspects, because these aspects will be different from one country to another. People faced new culture that are different from their own. These aspects could be language, habit, norm, and so on. Fan (2010) states that language shock is one of the less recognized aspects of cultural shock as its emotional impact is not so overtly strong that it could cause great harm or destruction to individuals who experience it (p. 42). This is shows that language is one of those aspects which can lead people to culture shock even the impact is not very strong, because language is part of culture that will be different from place to place.

In addition, a study found that there are fourteen aspects related to culture shock, they are as follows: communication, dress, ethics, individualism/collectivism, food, language, structure, perception, power distance, religion, rules, time orientation, traditions and weather (Rajasekar \& Renand, 2013, p. 149). In this case, the aspects of culture that experienced by people would be different, because culture is very wide. Every human activities can be considered as their culture. That is why it is almost impossible to say the exactly number of these aspects. The writer's findings were as follows: 


\section{Language}

In this study, the writer found that all of the four foreign workers experienced culture shock that related to language. Even though, not all of them really affected with this language aspect. Among the four foreign workers all of them experience culture shock related to language in the foreign country. As the four foreign workers stated:

(My language ability was only to say hello, we had an interpreter that provided by United Nation (UN). The interpreter was Indonesian that employed as language interpreter. They are paid by Persatuan Bangsa-Bangsa (PBB). The language is difficult especially for moslem who is not really master it. I mean Arabic)

(Yes, because of my language ability was very limited, it happened when I want to buy a train ticket between cities, I almost got into the wrong train)

(After being in the country for long time, I feel happy and keep the social relationship with the citizen of the host country, apparently Malaysian culture are alike my home country, it is just I am a little bit confuse about Melayu language, some of words sound strange)

(Things that I felt in the first week of my stay in Japan was a little bit worry, because I did not really understand the language, different food, and the situation was little bit quite compared to Indonesia, but after the first week. I think the language training was enough, we just have to learn more about it, because what we have learned during the training were only the basic)

To face language difference in the foreign country, the foreign workers have their own way to deal with this situation. Most of them deal with this language shock by using the knowledge given to them during the language training and also some other ways besides the training. Three of the foreign workers had training before the departure to the foreign country, one of them did not get a training at all as the four foreign workers mentioned:

(Yes, we had training, it is called "pra tugas" but it talk more about duty and language. We saw their culture through video based on the happening conflict)

(Yes, training or learning about language)

(In 1992, the first time I came to Japan, I got a training six months before the departure. We learned about language and also physical training)

(We had an interpreter that provided by United Nation (UN). They are paid by Persatuan Bangsa-Bangsa (PBB).)

(I always bring dictionary for daily conversation in my pocket.)

(There was miscommunication, but when I was curious I directly ask my friend who already understand Melayu Language.)

\section{Season}

In this study, the writer found three of the four foreign workers experienced different season in the host country that they never felt before. As they answered:

(The weather is very extreme, if it is cold, it is very cold. If it is hot, it is very hot) 
(When I was there I experienced those four seasons. Season that I dislike the most is winter, even Japanese themselves dislike it. For those who are not usual with winter, skin disease will appear. And then we did not do the activities as usual, spend more time at home. But it gets better when it is snow, not so cold)

(Yes, I experienced the winter until it reached -40 , and the second was summer, the temperature reached 450 C. Spring and winter are chilly)

To deal with different season they found in the foreign country, three of the four foreign workers have similar way, as they mentioned:

(Lots of physical treatment and doing sports regularly)

(Clearly I always dressed warm, some kind of sweater. Wearing gloves and boots when I went out)

(Clearly, I wore warm clothes in every activity. Working, hang out, sleeping, I wore double clothes. I used hot air conditioner, stopu (warmed lamp), ear cover, and gloves. I wore all of that during winter)

\section{Environment}

In this study, the writer found that all of the foreign workers experienced culture shock related to environment. They all found that the situation in the host country are very different from their home country. As the four foreign workers stated:

(I felt a little bit confuse because of the strange situation. It was strain because of in a conflict area. The conflict was about the territory border)

(I am amazed by the clean environment, there are no street vendors. People are discipline about time, and they obey the rules on the road)

(The most impressive thing when I arrived in Japan is about the clean environment. The situation is much different from our country. There is no rubbish on the road, everything is very well managed. They have the schedule to throw rubbish, and when they want to throw away electronic rubbish such as vehicle, bicycle, television, they have to pay for it. They have what they called as second stuff graveyard)

(I felt strange with Melayu culture in that country, but since I work at a construction, apparently there are many workers that came from my home country. It was beyond my expectation that I met many foreign workers from many countries)

They have their own way to deal with the strange environment while they were in a foreign country, as they mentioned:

(I asked to people who already there before me (we have an exchange every year) and adapted between duty and daily activities)

(Personally, we have to understand and try to tolerate the situation where foreign workers in Malaysia are from many different countries with many different culture) 


\section{Friends at Work}

In this study, the writer found that all the four foreign workers experienced culture shock related to their friends at work in the host country. As the four foreign workers answered:

(I felt awkward, they only gave smile and used sign to communicate)

(Friends there are more open and care. They really appreciate us as their guest, they were very helpful when we did our daily activities and also about the limitation of language that I have)

(A worker from Bangladesh always make noise in kongsi (temporary bedroom for workers), then I lost my patient, I collide the board between us with a hammer until it broke, luckily it did not hit the workers' head in that kongsi)

(Work is very much different. Japanese are crazy about work. They do not think about time. If their work have not finished, yet, they will not stop. They have a high responsibility, very different from us, the responsibility is still low, even though not everyone like that)

Those foreign workers found the solution to solve their unpleasant feeling dealing with new friends at work in the foreign country, as they mentioned:

(Yes, by learning their language and habit)

(Personally, we have to understand and try to tolerate the situation where foreign workers in Malaysia are from many different countries with many different culture)

(Thank God, worker from Bangladesh apologized and promise not to do like that again)

(To keep a good stamina, I take a bath in a hot water, drink vitamin and go to bed after work until midnight)

\section{Rules}

In this study, the writer found that three of the four foreign workers experienced the difference of rules between their home country and the host country. Three of the four foreign workers affected by the difference of rules, meanwhile rules in Australia did not affect one of them much. As the three foreign workers answered:

(The rules are different, we have to drive on the right side of the road. There is no night hour for women)

(Yes, the system is empire/ kingdom, the rules are very tight. They will get fine for throwing rubbish not in its place. Street vendors must have license for selling their things)

(They have the schedule to throw rubbish, and when they want to throw away electronic rubbish such as vehicle, bicycle, television, they have to pay for it. They have what they called as second stuff graveyard)

(If we ride the bicycle, we are not allowed to carry anyone on the back, even there is a seat for one more person) 
To deal with these new rules in the foreign country, those foreign workers found their own way to solve it, as they stated:

(We already told and practiced about it on pra-tugas in Sentul)

(Yes, we just have to follow it so we do not get fine)

(Place where I live was near the company, so I throw the rubbish there in PT. They will sort the rubbish there)

\section{Local People}

In this study, the writer found that three of four foreign workers experienced culture shock related to local people in the host country. Meanwhile this local people aspect did not affect the other much. As they mentioned:

(The locals' characteristics are very hard and ignorant but if we already know them, they are nice, and the suspicious level is very high, they think people from Asia are lower than them)

(Malaysian are really selective in choosing jobs. They are rarely want to work at a construction)

(They are ignorant, as long as we do not disturb them they will not care, but if they think we are suspicious, not long after that the police will come)

To deal with these phenomena, those foreign workers did something as the three foreign workers stated:

(We still be nice to them and tried to find out why they ignore us. We asked the people who got there first before us)

(I adapted by realize that people must respect each other and follow the rules by the company where I work in)

(We still greet them at the workplace, in the morning or after work to show that Indonesian are nice and kind. Therefore they will accept us)

\section{Food}

The writer found that the four foreign workers in this study faced similar situation in the host country related to food that they should eat there. As the four foreign workers answered:

(It took more time for us to adapt with the food because they do not eat rice. It hard for us because if we do not eat rice we do not feel full, yet)

(We try to adapt with the food there. We eat the same menu that they eat)

(The food is mostly made with milk squeezed from coconut, it some kind of curry. I do not like it, especially if it is too often)

(Yes, Japanese food are not fit with our tongue, it is tasteless, not spicy, and not sweet. It is like, it is unflavored. Most of the food are originate from there except the worldwide food such as McD and KFC, the taste are much the same)

To deal with this situation the four foreign workers had their own way, as they mentioned:

(They provided bread, but the unit officer was trying to get some of the breads 
to be exchanged with rice)

(Whether I want it or not, or I like it or not I have to, because people can because it is usual for them, Impossible become possible)

(I cooked by myself. I bought the material and cook it as I want. Usually we did it together, two until four person. It is thrifty)

(I brought tiny sea fish, supermie, and flavors from Indonesia. I cook by myself. Once a month, there is Japanese seller who sell Indonesian food such as noodles, sarden, and flavors, so it is not difficult to cook Indonesian food)

\section{Dress}

All of the four foreign workers in this study found something different related to the way people dressed in the host country. Their statements are as follows:

(The way they dressed especially European are very stylish. Some of them are syiah. Their clothes are much closed. But the men's way of dressed is similar as Asian)

(Men usually use short pants and t-shirt, and women are more likely to use mini skirt and tank top, their clothes are more open)

(The way people dress is the same as Indonesian, but the noble use traditional clothes)

(Generally the same, but in summer they use more open clothes, especially women, everything is very open. When it is winter, most of them dressed much closed)

Two of the four foreign workers not really affected with the way people dress in the foreign country but two of them had their own thoughts about it, as they mentioned:

(No, we used our uniform and dressed like when we are in Indonesia)

(It was not really hard to adapt with the way people dressed there, it was not really affect me much)

\section{Habit}

In this study, the writer found that three of the foreign workers experienced different habit that they found in the host country. Meanwhile, Australian habit did not really affect one of them much when he was there. As the three foreign workers said:

(They usually hang out at cafe and have a high life style. They do not want to get dirty like doing gotong-royong, they do not have that. They have janitors to do such a thing)

(It is moderate about entertainment and gambling because many Chinese have become the citizen of Malaysia)

(It is usual for us when we back home from work talking with neighbors, but not there. If they come home from work, their time is only for family. If they want to meet each other, they will meet at certain place such as café and so on) 
To adapt with these habit, two of them found the solution, meanwhile one of them had nothing to do about it because as a soldier he is not allowed to do the same thing (habit) as the locals do. Their statements are as follows:

(I tried to get to know the people who like gambling then I know their life is not better. So, I avoid that things to stay away from it)

(I lived near my other friends, so when I back from work I always talked, cooked with them. Japanese who are close to us always come by and have a conversation with us)

(We were as the one who monitored, we are not allowed to hang out at café and something like that. About to keep clean environment we were working together but only on our territory)

\section{Women-men relationship}

Among the four foreign workers in this study, three of them found the difference related to women-men relationship in the host country. Meanwhile the other found no difference about the relationship between men and women in Malaysia. It is similar as he experienced in Indonesia. Their statements are as follows:

(Their relationships are free and very much different from ours (well behave and manner). Most of them sit around doing nothing/ hang out. Women are free, there is no night hour for them)

(Yes, the relationship between men and women are free and open)

(The relationship between women and men are mostly the same, but there, they are really submissive with the rules of their culture)

To deal with the situation found in the foreign country, especially about relationship between men and women, they had similar way as they mentioned:

(I adapted there properly. I am from the east, and I respect my value and culture)

(It is danger if it is affected me and it means I broke the rules of military institution)

\section{DISCUSSIONS}

Based on the writer's findings, the writer found that her findings was in line with Fan (2010 and Rajasekar \& Renand (2013), but the writer also found another aspects beside those aspects that stated by them. Those aspects are environment, friends at work, rules, local people, habit, and women-men relationship. Based on the writer findings, the writer built 10 different categories of culture shock aspects as follows: language, season, environment, friends at work, rules, local people, food, dress, habit, and women-men relationship.

The first aspect is language. Language between countries are varying. This various kind of language cause a psychological reaction known as culture shock. One of the four foreign workers had an interpreter to help him communicate with people there. Since his main job was to make peace as a peacekeeper in a conflict area, he did need help to make his job easier to deal with. He was having difficulty in using Arabic to communicate but he had an interpreter.In the other hand, one of them was having difficulty in using English and one of them was having difficulty in using Japanese to communicate. Both did not have an interpreter. One of them who 
worked in Malaysia had difficulty in understanding Melayu language.

Another fact that three of them had a training before they leave their home country. The training was include language training, so they really prepared for the departure to the host country. Meanwhile, one of them had no training at all. He went to the host country illegally, because all of migrant workers through DEPNAKER will have their training before they leave their home country. Most of them deal with this language shock by using the knowledge given to them during the language training. Beside the training, one of them got help from an interpreter that provided by United Nation in doing his job in the foreign country, one of them brought dictionary everywhere he go, and one of them asked help from friends to tell him the words he did not understand.

It can be inferred that language training sometimes does not enough to make sure the foreign workers can communicate well in the foreign country. Commonly the training is given in a short time. Learning a new language in a short time is rather difficult, that is why foreign workers need to have another solution to deal with the foreign language.

The second aspect is season. Geographically, each country has different location. It cause the differences of season among them. Three of the four foreign workers do not like winter because it is very cold. They are not usual with the cold air because in Indonesia they only experienced dry and rain seasons. Meanwhile one of them did not experienced the difference of the season at all because the season in Malaysia is not very different from Indonesia. To deal with different season they found, especially winter, all of them wore warm clothes just like locals did there.

The third aspect is environment. The writer found that all of the foreign workers experienced culture shock related to environment. One of them who sent to Lebanon as a peacekeeper had to deal with a strain situation in a conflict area. A war situation is very much different from the situation in Indonesia. Meanwhile, two of them are amazed with the environment which is very clean there in the foreign country. Since two of the foreign workers in this study have positive responds to the new environment, there were nothing they can do about to deal with it. One of them who experienced strain situation in a conflict area, he asked about the situation of the environment to the soldier from the same country who got there first before them.

The fourth aspect is friends at work. When foreign workers work in a foreign country they will meet some new friends there. One of the four foreign workers found that his friends at work only using smile and sign to communicate.

Meanwhile one of them found that his new friends are more open and care to him. One among four who worked in Malaysia had a much different experience than others. He found that some of foreign workers from Bangladesh are noisy and it bothered him. He said that they almost had a fight because of this until that person from Bangladesh apologize to him. One of them who work in Japan found that Japanese are crazy about work. He said they are a hard worker, very much different from Indonesian he knows, even though not all Indonesian like that. Japanese will never leave their job undone.

When they met new friends in a foreign country, the situation forced them to adapt with those new friends whom they have not known before. One of them who worked in Australia has a positive respond to his friends at work, it is clear when he said that friends in Australia are more open and care. Meanwhile three of the four foreign workers found something different. 
One of them found that people used sign to communicate and to deal with it he try to learn their language. The one who work in Malaysia believe that people must appreciate each other. The one who worked in Japan that found Japanese are crazy about work and always work until midnight have to take care himself very carefully.

Based on the four foreign workers experiences, it can be inferred that to adapt with new friends in a new workplace, people must follow and understand the happening situation. Therefore, they will find ways to deal with the strange situation they have not seen and experienced before in their home country.

The fifth aspect is rules. Each country has its own rules to control its people. One of them who worked in Lebanon found that he had to drive on the right side of the road there. One of them found that in Malaysia people must throw rubbish in its place or they will get find. He also found that street vendors must have license to sell their things. Another who experienced different rules in Japan found that people in Japan have schedule for throwing the rubbish.

New environment brought them to new rules of life in the foreign country. Since every country has their own rules, foreign workers must be able to adapt with these new rules to survive there. One of them already got some kind of training related to rules in the new country.

Again, the impact of training is really helpful for the foreign workers. Just like the person said that he already had a practice about rules on the road in the foreign country before the departure there. At this point, it can be inferred that those foreign workers dealing with the difference of rules by prepared before they got to foreign country and follow the rules as the best as they can when they are there.

The sixth aspect is local people. People from one country will be different from other country, physically, culturally and so on. One of the four foreign workers found that people in Lebanon are ignorant and the level of suspicious is very high because that is a conflict area. One of them found that people in Malaysia are really selective in choosing jobs. The other found that people in Japan are ignorant and wary. In this case, it seems that local in these different countries have different characteristics. To deal with these phenomena, those foreign workers did something such as asked the people who already know about it and keep social relationship with them.

The seventh aspect is food. There are various food in many different countries. One of the four foreign workers who sent to Lebanon found that people there do not eat rice but bread. To deal with this situation he and his friends tried to do something which is why the officer unit tried to find a way to exchange some of the bread with rice

In the other hand, one of them who at the first dislike the food in Australia became to like it at the end. One of them found that most of the food in Malaysia are curry. The same case happened to the other one who found the food in Japan are tasteless like it is unflavored. Both of them chose to cook by themselves, so they still able to taste Indonesian food in the foreign country.

The eighth aspects is dress. One of the four foreign workers found that people in Lebanon with Syiah majority, their clothes are much closed. In the other hand, one of them found that people use more open clothes in Australia. The other one found that the way people dressed in the host country is similar with Indonesian. Meanwhile in Japan, one of them found that people use open clothes in summer but much closed in winter. All the four foreign workers not really affected with the way people dress in the foreign country. They dressed as usual like they did 
in their home country and dressed depends on what season in the foreign country.

The ninth aspect is habit. People in different country have different habit. One of the foreign workers said that people in Lebanon always use the janitor service to make sure their environment clean. They do not have what we called as gotong-royong (working together to keep a clean environment) in Indonesia and they often hang out. This situation did not affect him much because they only monitoring the situation.

One of them found that entertainment and gambling are become habit in Malaysia. In the other hand, the other found something different about people habit after work in Japan, that people in Japan spend their time after work special for their family, it is different from what he experienced in Indonesia where people sometimes talk with neighbors after their work time. To adapt with these kind of habit they both tried to keep their own value.

The last aspect that the writer found in this study is women-men relationship. Three of the four experienced culture shock related to this aspect except the one who worked in Malaysia who found no difference about the relationship between men and women in Malaysia. It is similar as he experienced in Indonesia. Three of them found it is more open compare to what happen in their home country. To deal with this situation, most of them still hold on their own value and culture. They never forget of where they are came from. It is best if people adapt properly in the foreign country when they are there and keep their own value and culture with them.

\section{CONCLUSION}

Based on the discussion in previous chapters, there are ten aspects of culture shock experienced by the four foreign workers in this study. Six aspects among the ten were experienced by all of the four subjects. Those six aspects are language, environment, friends at work, food, dress, and women-men relationship. Meanwhile, the rest four aspects were only experienced by some of them. The four aspects are season, rules, local people, and habit. In dealing with culture shock, the four foreign workers found various solutions depend on what aspect of culture they were dealing with when adapting in the foreign country they were work in, but from all the solutions, the important thing is that they are still hold on their own value and culture.

\section{References}

Ariss, A. A., \& Crowley-Henry, M. (2013). Self-initiated expatriation and migration in the management literature Present Theorizations and future research directions. Career Development International, 78-96.

Avruch, K. (2002). Culture and Conflict Resolution. NY: United States Institute of Peace Press.

Bogdan, R. C., \& Biklen, S. K. (2003). Qualitative Research for Education. NY: Pearson Education Group, Inc.

Brooker, P. (2003). A Glosary of Cultural Theory. NY: Oxford University Press Inc.

Fan, S. (2010). Language Shock: A Challenge to Language Learning. The International Journal - Language Society and Culture, 42-51.

Hofstede, G., Hofstede, G. J., \& Minkov, M. (2010). Cultures and Organizations: software of the mind: Intercultural Cooperation and Its Importance for Survival. NY: McGraw- Hill Companies.

Indonesia, P. R. (2003). Indonesia Patent No. 13.

Irawan, R. (2014). Tenaga Kerja Indonesia (TKI) Dan Kehidupan Sosial Ekonomi: Studi Tentang Masyarakat Yang Bekerja Sebagai Tenaga Kerja Indonesia Di Desa Lembah Kecamatan Dolopo Kabupaten Madiun. Surabaya: UIN Sunan Ampel.

Pelling, A. C. (2000). Culture Shock of International Students in Canada. Lethbridge: Alberta. 
Przytuła, S. (2015). Migrants, Assigned Expatriates (AE) and Self-initiated Expatriates (SIE) - Dfferentiation of Terms and Literature- Based Research Review. Journal of Intercultural Management, 89-111.

Rajasekar, J., \& Renand, F. (2013). Culture Shock in a Global World: Factors Affecting Culture Shock Experienced by Expatriates in Oman and Omani Expatriates Abroad. International Journal of Business and Management, 144160.

Richards, J. C., \& Schmidt, R. (2002). Longman Dictionary of Language Teaching and Applied Linguistics. London: Pearson Education Limitied.

Susanti, R. (2016). Students' Perceptions Towards the Effective Feedback Practices in The Large EFL Writing Class Based On Students' English Proficiency Level. Journal of Advances in Linguistics, 1063-1069.

Syahri, I., \& Susanti, R. (2016). An Analysis of Local and Target Culture Integration in the English Textbooks for Senior High School in Palembang. Journal of Education and Human Development, 1-7.

Syahri, I., Sulaiman, M., \& Susanti, R. (2017). Metodologi Penelitian Pendidikan Bahasa. Palembang: Roemah Sufie.

Sziraczki, G., \& Reerink, A. (2004). Transisi Dari Sekolah Menuju Dunia Kerja Di Indonesia. Jakarta: Kantor Perburuhan Internasional.

Winkelman, M. (1994). Cultural Shock and Adaptation. Journal of Counseling and Development, 121-126.

Zikic, J., Pérez, J. B., \& Cerdin, J.-L. (2010). Crossing National Boundaries: A typology of qualified immigrants' career orientations. Journal of Organizational Behavior, 667-686. 